\title{
Biological control of the onion thrips, Thrips tabaci Lindeman (Thysanoptera: Thripidae), in open fields using Egyptian entomopathogenic nematode isolates
}

\author{
Ahmed M. Azazy ${ }^{1 *}$, Manal Farouk M. Abdelall², Ibrahim A. El-Sappagh ${ }^{1}$ and A. E. H. Khalii ${ }^{1}$
}

\begin{abstract}
Entomopathogenic nematodes (EPNs) of families Heterorhabditidae and Steinernematidae are known to be effective against a variety of pests. In the present work, different EPNs that are isolated from the Egyptian environment were tested against the onion thrips, Thrips tabaci Lindeman (Thysanoptera: Thripidae), under field conditions. The Egyptian EPNs were tested at different concentrations and against different onion thrips stages (adult and nymph). When used as a foliage spray, the tested EPN isolates were efficient against both adult and nymph stages. Differences in pathogenicity were observed within the same EPN species as in Heterorhabditis indica (EGAZ3) that caused higher reduction in population of T. tabaci (adult and nymph) after 24 and $48 \mathrm{~h}$ at a concentration of 10,000 infective juveniles (IJs)/ml compared to $\mathrm{H}$. indica (EGAZ2) after $24 \mathrm{~h}$ post treatment at a concentration of $15,000 \mathrm{IJs} / \mathrm{ml}$. The same pattern was observed with Heterorhabditis bacteriophora (HP88), where a higher reduction percent was recorded after $24 \mathrm{~h}$ at a concentration of 20,000 IJs/ml. On the other hand, Steinernema carpocapsae (All), S. carpocapsae (EGAZ9), and S. carpocapsae (BA2) isolates were less effective in controlling onion thrips (adult and nymph) population. In general, controlling T. tabaci at the nymphal stage was more efficient than at the adult stage (12-73\% reduction at the nymph stage compared to $6-65 \%$ at the adult stage). It was also found that increasing inoculation concentration above 15,000 $\mathrm{IJs} / \mathrm{ml}$ had no significant difference in controlling onion thrips populations.
\end{abstract}

Keywords: Entomopathogenic nematodes (EPNs), Thrips tabaci, Field conditions, Biological control

\section{Background}

Onion, Allium cepa L. (Amaryllidaceae (Alliaceae), is an important cash crop in Egypt for local consumption and exportation. Onion plants are infested with different insect pests throughout their growing season (Mahmoud, 2008 and Diaz-Montano et al., 2011). One of the major destructive pests of onion is onion thrips, Thrips tabaci Lindeman (Thysanoptera: Thripidae), which feeds on onion plants during their vegetative growth and fruit filling (Mahmoud, 2008).

Management of $T$. tabaci has proved to be problematic, due to its minute size and its thigmotactic behavior

\footnotetext{
* Correspondence: drahmedmohammed98@yahoo.com;

manalfm@ageri.sci.eg

${ }^{1}$ Plant Protection Research Institute (PPRI), Agricultural Research Center (ARC),

7 Nady El-Said St., Dokki, Giza, Egypt

Full list of author information is available at the end of the article
}

(Lewis, 1997). Traditionally, controlling thrips is conducted via the usage of chemical applications, which may explain the widespread chemical-resistance development in onion thrips (Jensen, 2000). Entomopathogenic nematodes (EPNs) as one of the biological control agents are obligate pathogens, which possess free-living third stage infective juvenile (IJ) characteristics. This characteristic, in particular, enables them to kill insects via releasing their symbiotic mutualistic bacteria (Xenorhabdus and Photorhabdus in Steinernema and Heterorhabditis, respectively), which, in turn, causes insect death within 24-48 h (Kaya and Gaugler, 1993 and Gaugler, 2002).

EPNs have been used successfully as an alternative to traditional pesticides in controlling several pests localized in soil, caterpillars, leaf miners, and thrips (Williams and Walters, 2000 and Laznik et al., 2010). EPNs have been used to control larval stages of western flower thrips 
(WFT), Frankliniella occidentalis, in ornamental plants and greenhouse vegetables (Wardlow et al., 2001 and Trdan et al., 2007b). Foliar applications of the IJ stage for both Steinernema feltiae (Filipjev) and Lecanicillium muscarium (Petch) were found to offer various levels of control over other quarantine invertebrate pest species including leaf miners and whiteflies (Williams and Walters, 2000 and Cuthbertson and Walters, 2005).

Onion thrips feed on the transition-zone parts of leaves (pale green color) that provides an ideal situation to control infestation at early stages (Theunissen and Legutowska, 1991). Therefore, foliage spray to this zone could increase the efficiency of EPN application against onion thrips (Shiberu and Mohammed, 2014). For this reason, the weak activity associated with foliage applications could be due to the negative efficiency of high temperature, low humidity, and direct exposure to sunlight (Shapiro-Ilan et al., 2006 and Jung, 2008).

In the present work, the efficiency of foliar application of several Egyptian EPN isolates was tested against the onion thrips under field conditions.

\section{Methods}

All EPN isolates used in this study were reared at $25 \pm 2^{\circ}$ $\mathrm{C}$ in greater wax moth larvae Galleria mellonella L. (Lepidoptera: Pyralidae), following the procedure of Ehlers and Shapiro-Ilan (2005). Six isolates of EPNs were used: four were isolated from Egyptian soil (Heterorhabditis indica (EGAZ2), H. indica (EGAZ3), Steinernema carpocapsae (EGAZ9), and S. carpocapsae (BA2), unpublished data) and two were imported from Biosys Palo Alto, CA (USA) (Heterorhabditis bacteriophora (HP88) and S. carpocapsae (All)) (Table 1).

In general, IJs were acclimatized through soaking in tap water for at least $5 \mathrm{~h}$ at room temperature before usage. Different concentrations (i.e. 10,000, 15,000, and 20,000 IJs $/ \mathrm{ml}$ ) of EPNs were prepared following the nematode quantification method (Woodring and Kaya, 1988 and

Table 1 Six entomopathogenic nematode isolates (EPNs) tested to control Thrips tabaci in field treatments

\begin{tabular}{ll}
\hline Strains of EPN & Source \\
\hline $\begin{array}{l}\text { Heterorhabditis bacteriophora (HP88) } \\
\text { Steinernema carpocapsae (All) }\end{array}$ & Biosys, Palo Alto, CA (USA) \\
Heterorhabditis indica (EGAZ2) & $\begin{array}{l}\text { Isolated from Ismailia } \\
\text { Governorate, Egypt,by Azazy } \\
\text { et al. (unpublished data) }\end{array}$ \\
$\begin{array}{l}\text { Accession no. KY088204 } \\
\text { Accession no. KY088205 }\end{array}$ & \\
Steinernema carpocapsae (EGAZ9) & Isolated from Sharkia \\
Accession no. KY088211 & $\begin{array}{l}\text { Governorate, Egypt, by Azazy } \\
\text { et al. (unpublished data) }\end{array}$ \\
Steinernema carpocapsae (BA2) & $\begin{array}{l}\text { Isolated by Hussein and } \\
\text { Abou El-Soud (2006) }\end{array}$ \\
\hline
\end{tabular}

Kaya and Stock, 1997). A formulation of 0.1\% Tween 80 was added to the nematode suspension to maximize the efficiency of onion leave coating while spraying.

The experiment was conducted at the experimental research station, Faculty of Agriculture, Benha University. Onion seedlings, var. Giza 20, were planted in December 2015 using the recommended agriculture practices, while in 2016 the onion seedlings were planted on the last week of March at the experimental site. A complete randomized block design ( quarter feddan) with four replicates was implemented; each replicate consisted of four 12-m-long rows; the distance between rows was $10 \mathrm{~cm}$ with $5 \mathrm{~cm}$ distance among the plants; and a $1-\mathrm{m}$ long distance was used to separate each block.

The trail started when thrips population (adults and nymphs) was at its peak. The thrips number on plants was counted immediately before treatment and 24 and $48 \mathrm{~h}$ post treatment by randomly selecting five plants and vigorously shaking them over a white sheet.

Foliage application was performed in the open field $3 \mathrm{~h}$ before sunset (at $\sim$ 4:00 PM). The spray was conducted by directing the nozzle to the plant base, as well as the surrounding soil. The control plots were sprayed with water. The reduction in thrips population was calculated using Henderson and Tilton equation (Henderson and Tilton, 1955). Thrips were considered dead when they did not respond to mechanical stimulation and showed discoloration symptoms. Furthermore, random cadavers were selected for dissection and examination under a binocular microscope to confirm the presence of EPN inside.

For statistical analysis, the percentage reduction values in the present study were normalized using arcsine transformation. The significance of the main effects was performed using analysis of variance (ANOVA), Duncan's multiple range test $(P<0.05)$, and SAS program (SAS Institute, 2002).

\section{Results and discussion}

Effect of EPN applications against onion thrips population In general, all EPN applications caused measurable reductions in T. tabaci nymph and adult population 24 and $48 \mathrm{~h}$ post treatment.

For the adult stage, at a concentration of 10,000 IJs/ $\mathrm{ml}$, a significant reduction in thrips population (65.6\%) was achieved using "EGAZ3" isolate, followed by "All" isolate (55.8\%), $24 \mathrm{~h}$ post treatment (Fig. 1a), while after $48 \mathrm{~h}$ "EGAZ3" isolate still caused the highest mortality rate, followed by "EGAZ9," "All," and "EGAZ2" (47.1, $46.8,37.9$, and $33.4 \%$, respectively (Fig. 2a). At a concentration of $15,000 \mathrm{IJs} / \mathrm{ml}$, the thrips adult population was reduced significantly to 62.1 and $55.2 \% 24$ h post treatment with "EGAZ2" and "HP88" isolates, respectively 


\section{A}
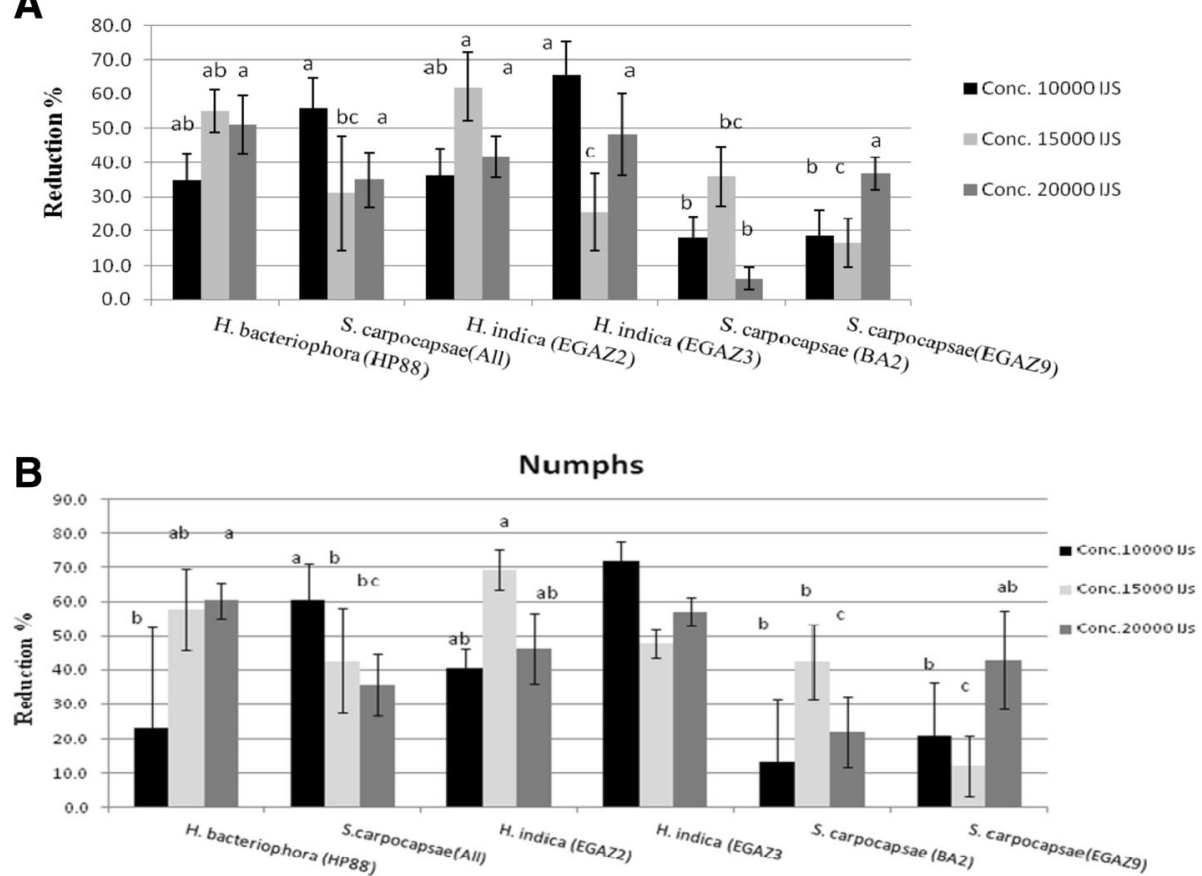

Fig. 1 Reduction percentage for different treated stages using the EPNs after $24 \mathrm{~h}$ at different concentrations: a for T. tabaci adults, b for T. tabaci nymphs. Columns annotated with the same letter are not significantly different $(P<0.05)$
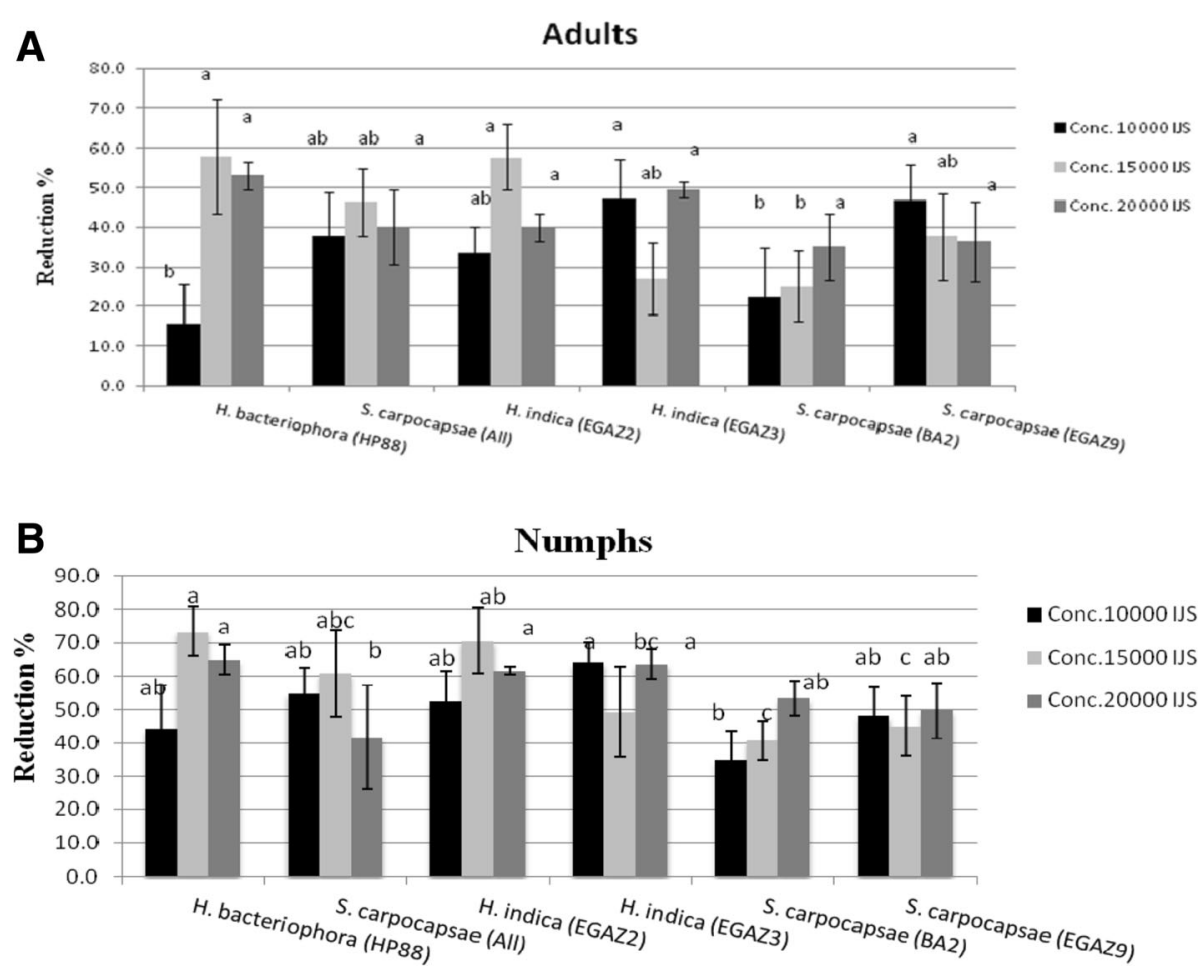

Fig. 2 Reduction percentage for different treated stages using the EPNs after $48 \mathrm{~h}$ at different concentrations: a for T. tabaci adults, $\mathbf{b}$ for $T$. tabaci nymphs. Columns annotated with the same letter are not significantly different $(P<0.05)$ 
Table 2 Mean reduction (\%) of life stages of onion thrips as induced by six different entomopathogenic nematode isolates (EPNs) at different concentrations

\begin{tabular}{|c|c|c|c|c|c|c|c|c|c|c|c|c|}
\hline \multirow{3}{*}{$\begin{array}{l}\text { Concentrations } \\
(\mathrm{IJs} / \mathrm{ml})\end{array}$} & \multicolumn{12}{|c|}{ Mean reduction $\% \pm \mathrm{SE}^{*}$} \\
\hline & \multicolumn{2}{|c|}{$\begin{array}{l}\text { H. bacteriophora } \\
\text { (HP88) }\end{array}$} & \multicolumn{2}{|c|}{ S. carpocapsae (All) } & \multicolumn{2}{|c|}{ H. indica (EGAZ2) } & \multicolumn{2}{|c|}{ H. indica (EGAZ3) } & \multicolumn{2}{|c|}{$\begin{array}{l}\text { S. carpocapsae } \\
\text { (BA2) }\end{array}$} & \multicolumn{2}{|c|}{$\begin{array}{l}\text { S. carpocapsae } \\
\text { (EGAZ9) }\end{array}$} \\
\hline & Adults & Nymphs & Adults & Nymphs & Adults & Nymphs & Adults & Nymphs & Adults & Nymphs & Adults & Nymphs \\
\hline 10,000 & $\begin{array}{l}52.28 \pm \\
17.1 \mathrm{~b}\end{array}$ & $\begin{array}{l}33.77 \pm \\
20.1 \mathrm{~b}\end{array}$ & $\begin{array}{l}46.83 \pm \\
9.7 a\end{array}$ & $\begin{array}{l}57.6 \pm 8.6 \\
a\end{array}$ & $\begin{array}{l}34.78 \pm \\
7.3 \mathrm{~b}\end{array}$ & $\begin{array}{l}46.48 \pm \\
7.1 \mathrm{~b}\end{array}$ & $\begin{array}{l}56.4 \pm 4.8 \\
a\end{array}$ & $\begin{array}{l}66.0 \pm \\
1.2 \mathrm{a}\end{array}$ & $\begin{array}{l}20.2 \pm \\
16.6 \mathrm{a}\end{array}$ & $\begin{array}{l}24.05 \pm \\
12.9 a\end{array}$ & $\begin{array}{l}32.76 \pm \\
10.9 a\end{array}$ & $\begin{array}{l}34.58 \pm \\
11.1 \mathrm{a}\end{array}$ \\
\hline 15,000 & $\begin{array}{l}56.52 \pm \\
10.1 \mathrm{a}\end{array}$ & $\begin{array}{l}65.62 \pm \\
9.4 \mathrm{a}\end{array}$ & $\begin{array}{l}38.75 \pm \\
8.4 \mathrm{a}\end{array}$ & $\begin{array}{l}51.82 \pm \\
10.1 \mathrm{ab}\end{array}$ & $\begin{array}{l}59.9 \pm \\
6.4 \mathrm{a}\end{array}$ & $\begin{array}{l}69.93 \pm \\
7.5 \mathrm{a}\end{array}$ & $\begin{array}{l}26.23 \pm \\
14.3 \mathrm{~b}\end{array}$ & $\begin{array}{l}60.33 \pm \\
7.5 \mathrm{a}\end{array}$ & $\begin{array}{l}30.5 \pm \\
5.1 \mathrm{a}\end{array}$ & $\begin{array}{l}41.58 \pm \\
5.1 \mathrm{a}\end{array}$ & $\begin{array}{l}27.1 \pm 9.7 \\
a\end{array}$ & $\begin{array}{l}28.48 \pm \\
4.5 \mathrm{a}\end{array}$ \\
\hline 20,000 & $\begin{array}{l}52.03 \pm \\
4.5 \mathrm{a}\end{array}$ & $\begin{array}{l}62.58 \pm \\
3.8 \mathrm{a}\end{array}$ & $\begin{array}{l}37.6 \pm \\
8.3 a\end{array}$ & $\begin{array}{l}38.78 \pm \\
11.8 \mathrm{~b}\end{array}$ & $\begin{array}{l}40.85 \pm \\
7.3 b\end{array}$ & $\begin{array}{l}54.03 \pm 5 \\
\text { b }\end{array}$ & $\begin{array}{l}48.8 \pm 6.2 \\
a\end{array}$ & $\begin{array}{l}48.57 \pm \\
4.5 \mathrm{~b}\end{array}$ & $\begin{array}{l}20.7 \pm 1 \\
a\end{array}$ & $\begin{array}{l}37.63 \pm \\
4.5 \mathrm{a}\end{array}$ & $\begin{array}{l}36.58 \pm \\
9.2 \mathrm{a}\end{array}$ & $\begin{array}{l}46.48 \pm \\
4.5 a\end{array}$ \\
\hline$F$ & 6.47 & 5.54 & 0.71 & 2.42 & 13.57 & 7.65 & 6.72 & 7.37 & 0.69 & 1.75 & 0.26 & 1.46 \\
\hline P & 0.0094 & 0.0157 & 0.51 & 0.123 & 0.0004 & 0.0051 & 0.0083 & 0.0059 & 0.52 & 0.208 & 0.783 & 0.263 \\
\hline LSD & 20.015 & 26.89 & 18.1 & 18.63 & 10.7 & 13.05 & 18.22 & 10.87 & 21.15 & 20.98 & 22.9 & 22.7 \\
\hline
\end{tabular}

*\% reduction within a row followed by the same letters are not significantly different at $(P<0.05)$

(Fig. 1a), while $48 \mathrm{~h}$ post treatment, the reduction caused by "HP88" and "EGAZ2" isolates were almost the same (57.9 and $57.7 \%$, respectively). Increasing the concentration to $20,000 \mathrm{IJs} / \mathrm{ml}$ did not significantly improve the mortality rate in thrips either after $24 \mathrm{~h}$ (51.0 and 48.2\% reduction in "HP88" and "EGAZ3" isolates, respectively) or after 48 h (53.0 and 49.3\% reduction in "HP88" and "EGAZ3" isolates, respectively) (Figs. 1a and 2a).

For the nymphal stage, at a concentration of 10,000 $\mathrm{IJ} / \mathrm{ml}$, a significant reduction in thrips population was observed 24 h post treatment (71.8\% using "EGAZ3" isolate, followed by $60.4 \%$ for "All" isolate) (Fig. 1b). At $15,000 \mathrm{IJs} / \mathrm{ml}$ of "EGAZ2" and "HP88," the highest nymph mortality with 69.6 and $57.8 \%$, respectively, was observed. Similar to the obtained results on adults, increasing the concentration to $20,000 \mathrm{IJs} / \mathrm{ml}$ did not improve the mortality rate in nymphs, $24 \mathrm{~h}$ post treatment (Fig. 1b). In general, measuring mortality rates in nymphs $48 \mathrm{~h}$ post treatment was not significantly different than after $24 \mathrm{~h}$ (Fig. 2b).

Data in Table 2 revealed that isolate "EGAZ2" had the highest reduction (59.9 and 69.9\%) of adults and nymphs, respectively, at a concentration of 15,000 IJs/ $\mathrm{ml}$. There were significant differences in the mortality levels achieved when comparing adults vs. nymphs; for example, at a concentration of 10,000 IJs/ml, "EGAZ3" isolate caused more reduction in nymphs than adults (56.4 and $66.0 \%$, respectively); these differences were tested at all concentrations. Moreover, isolates "All," "EGAZ9," and "BA2" were found to be the least effective (Table 2). The results clearly revealed that significant reduction in onion thrips population (at nymph and adult stages) was achieved upon EPN treatments; significant differences were observed among the different isolates used, yet no differences were observed in onion thrips mortality percentage among the different concentrations (Table 3).
It is well-known that EPN species/strains could vary tremendously in their virulence (expressed in terms of pathogenicity) against different host insects (Laznik et al., 2010), and their efficiency is highly affected by different factors including concentration, host density, and temperature (Trdan et al., 2009). EPN foliage application to control thrips in onion could be an applicable method (Trdan et al., 2007a, b), where spraying application could provide an effective way to cover leaves and parts of plants that are not exposed to direct sunlight (preferable infective areas for thrips).

Results presented by Premachandra et al. (2003) and Ebssa et al. (2004) suggested that western flower thrips (WFT) was more susceptible to Heterorhabditis than to Steinernema species/strains. Therefore, Ebssa et al. (2004) used S. carpocapsae strain "S.S2" isolated from Egypt and compared it to "A1 B5" isolated from Italy, and found that the Egyptian strain caused significantly higher mortality in WFT than the Italian strain, which

Table 3 Summary of ANOVA results for reduction \% of different T. tabaci life stages caused by different treated concentrations $(10,000,15,000$ and $20,000 \mathrm{lJs} / \mathrm{ml})$ of entomopathogenic nematodes (EPNs)

\begin{tabular}{|c|c|c|c|}
\hline & df & $F$ & P \\
\hline \multicolumn{4}{|l|}{ Sources } \\
\hline EPNs & 5 & 11.35 & $0.0007^{* * *}$ \\
\hline EPN concentration & 2 & 1.03 & $0.3935 \mathrm{~ns}$ \\
\hline Life stage & 1 & 11.48 & $0.0069^{* *}$ \\
\hline \multicolumn{4}{|l|}{ Interaction } \\
\hline EPNs $\times$ EPN concentration & 7 & 3.32 & $0.0358^{*}$ \\
\hline EPN concentration $\times$ life stage & 3 & 1.37 & $0.2984 n s$ \\
\hline EPNs $\times$ life stage & 6 & 0.93 & $0.6121 \mathrm{~ns}$ \\
\hline EPNs $\times$ EPN concentration $\times$ life stage & 8 & & \\
\hline
\end{tabular}


may be explained by differences in geographical origin and environmental adaptation.

On the other hand, Ebssa et al. (2001) reported that $H$. indica "LN2" isolate was more effective, in terms of its foraging behavior, than S. bicornutum. Similarly, H. bacteriophora was five times more effective than S. carpocapsae, in controlling prepupa of T. tabaci (Kamali et al., 2013).

The usage of nematodes to control thrips has been reported and suggested by some authors (Cuthbertson and Walters, 2005; Buitenhuis and Shipp, 2005). EPNs may offer a more suitable solution to deal with sedentary/settled insect pests (immature stage of Bemisia tabaci (Gennadius)) (Cuthbertson and Walters, 2005) or in the case of leaf-mining larvae (Williams and Walters, 2000). It was suggested that susceptibility of the nymph stage in onion thrips to EPNs is directly related to the nymph's limited mobility (Buitenhuis and Shipp, 2005); therefore, it was no surprise that Thrips palmi larvae were more susceptible to $S$. feltiae infection compared to adults (North et al., 2006).

In our results, a significant difference was found between the Egyptian isolates and the isolates from the USA. This finding is in line with Premachandra et al. (2003) who found no differences in mortality rate of WFT when commercial isolates (S. fetiae Nemaplus ${ }^{\circ}$ ) vs. local isolates (H. bacteriophora HD01) were compared, while contradicting the results reached by Helyer et al. (1995).

Foliage application of EPN was recommended by different groups to control WFT in Verbena leaves (Wardlow et al., 2001) by spraying $S$. feltiae to control the population of $F$. occidentalis (Arthurs and Heinz, 2006).

In the present work, use of different studied IJ/ml concentrations of the tested EPNs was found to have a little effect on increasing the reduction rate of onion thrips, which is in agreement with Premachandra et al. (2003), Ebssa et al. (2004), Kamali et al. (2013), and Kashkouli et al. (2014).

\section{Conclusions}

In conclusion, we demonstrate the efficiency of using EPNs in biological control of onion thrips under an open field condition in Egypt.

\section{Acknowledgements}

The authors would like to express their special thanks to Dr. Mohamed S. Tawfik for his effort during the writing of this manuscript.

\section{Author Contributions}

AMA designed and supervised the overall experiment. IAE and AEHA carried out the field experiment and recording data. MFMA performed sequence analysis to identify the isolated by molecular techniques and interpreted the results and wrote the manuscript. All authors read and approved the final manuscript.

\section{Competing interests}

The authors declare that they have no competing interests.

\section{Publisher's Note}

Springer Nature remains neutral with regard to jurisdictional claims in published maps and institutional affiliations.

\section{Author details}

${ }^{1}$ Plant Protection Research Institute (PPRI), Agricultural Research Center (ARC), 7 Nady El-Said St., Dokki, Giza, Egypt. ${ }^{2}$ Microbial Molecular Biology Department, Agricultural Genetic Engineering Research Institute (AGERI), Agricultural Research Center (ARC), 9 Gamaa St., 12619 Giza, Egypt.

Received: 7 September 2017 Accepted: 19 December 2017 Published online: 01 March 2018

\section{References}

Arthurs S, Heinz KM (2006) Evaluation of the nematodes Steinernema feltiae and Thripinema nicklewoodi as biological control agents of western flower thrips Frankliniella occidentalis infesting chrysanthemum. Biocontrol Sci Technol 16:141-155

Buitenhuis R, Shipp JL (2005) Efficacy of entomopathogenic nematode Steinernema feltiae (Rhabditida: Steinernematidae) as influenced by Frankliniella occidentalis (Thysanoptera: Thripidae) developmental stage and host plant stage. J Econ Entomol 98:1480-1485

Cuthbertson AGS, Walters KFA (2005) Evaluation of exposure time of Steinernema feltiae against second instar Bemisia tabaci. Tests Agrochem Cultivars 26:34-35

Diaz-Montano J, Fuchs M, Nault BA, Fail J, Shelton AM (2011) Onion thrips (Thysanoptera: Thripidae): a global pest of increasing concern in onion. J Econ Entomol 104(1):1-13

Ebssa L, Borgemeister C, Berndt O, Poehling HM (2001) EYcacy of entomopathogenic nematodes against soil-dwelling life stages of western flower thrips, Frankliniella occidentalis (Thysanoptera: Thripidae). J Invertebr Pathol 78:119-127

Ebssa L, Borgemeister C, Poehling HM (2004) Effectiveness of different species/ strains of entomopathogenic nematodes for control of western flower thrips (Frankliniella occidentalis) at various concentrations, host densities, and temperatures. Biol Control 29:145-154

Ehlers RU, Shapiro-llan DI (2005) Mass production. In: Grewal PS, Ehlers RU, Shapiro-llan DI (eds) Nematodes as biocontrol agents. CABI Publishing, Wallingford, pp 65-79

Gaugler R (2002) Entomopathogenic entomology. CABI Publishing, Wallingford

Helyer NL, Brobyn PJ, Richardson PN, Edmondson RN (1995) Control of western flower thrips (Frankliniella occidentalis Pergande) pupae in compost. Ann Appl Biol 127:405-412

Henderson CF, Tilton W (1955) Tests with Acaricides against the brown wheat mite. J Econ Ent 48(2):157-161

Hussein MA, Abou El-Soud AB (2006) Isolation and characterization of two Heterorhabditids and one Steinernematid nematodes from Egypt. Intern J Nemat 16:7-12

Jensen SE (2000) Insecticide resistance in the western flower thrips, Frankliniella occidentalis. Integr Pest Manag Rev 5:131-146

Jung K (2008) Biological control of Thrips tabaci in the field-possibilities and practical limits. IOBC/wprs Bulletin 31:344-348

Kamali S, Karimi J, Hosseini M, Campos R, Duncan LW (2013) Biocontrol potential of the entomopathogenic nematodes Heterorhabditis bacteriophora and Steinernema carpocapsae on cucurbit fly, Dacus ciliatus (Diptera: Tephritidae). Biocontrol Sci Tech 23:11

Kashkouli M, Khajehali J, Poorjavad N (2014) Impact of entomopathogenic nematodes on Thrips tabaci Lindeman (Thysanoptera: Thripidae) life stages in the laboratory and under semi-field conditions. J Biopest 7(1):77-84

Kaya HK, Gaugler R (1993) Entomopathogenic nematodes. Annu Rev Entomol 38:181-206

Kaya HK, Stock SP (1997) Techniques in insect nematology. In: Lacey LA (ed) Manual of techniques in insect pathology. Academic Press, San Diego, pp 281-324

Laznik Ž, Toth T, Lakatos T, Vidrih M, Trdan S (2010) Control of the Colorado potato beetle (Leptinotarsa decemlineata [Say]) on potato under field conditions: a comparison of the efficacy of foliar application of two strains of Steinernema feltiae (Filipjev) and spraying with thiametoxam. Journal of plant diseases and protection: scientific journal of the German phytomedical society (DPG) 117(3):129-135 
Lewis T (1997) Pest Thrips in perspective. In: Thrips as crop pests. Lewis T. (Ed.). Wallingford, CAB Int, pp 1-13

Mahmoud HH (2008) Ecological studies on certain insect pests of onion with special emphasis on the onion bulb fly Eumerus anoenus Loew. Ph.D.Thesis, Fac., Agric., Cairo Unvi, Egypt

North JP, Cuthbertson AGS, Walter KFA (2006) The efficacy of two entomopathogenic biocontrol agents against adult Thrips palmi (Thysanoptera: Thripidae). J Invert Pathol 92:89-92

Premachandra D, Borgemeister C, Berndt O, Ehlers RU, Poehling HM (2003) Laboratory bioassays of virulence of entomopathogenic nematodes against soil inhabiting stages of Frankliniella occidentalis Pergande (Thysanoptera: Thripidae). Nematology 5:539-547

SAS Institute (2002) SAS/stat user's quide version 9.1.3. SAS institute, Cary, NC

Shapiro-llan DI, Gouge DH, Piggott SJ, Fife JP (2006) Application technology and environmental considerations for use of entomopathogenic nematodes in biological control. Biol Control 38(1):124-133

Shiberu T, Mohammed A (2014) The importance and management option of onion thrips, Thrips tabaci (L.) (Thysanoptera: Thripidae) in Ethiopia: a review. Entomol Appl Sci Letters 1(2):1-8

Theunissen J, Legutowska H (1991) Thrips tabaci Lindeman (Thysanoptera, Thripidae) in leek - within-plant distribution. J Appl Entomol 112:309-316

Trdan, S.; Luka K. and Matej V. 2007a. First results concerning the efficacy of entomopathogenic nematodes against Hercinothrips femoralis (Reuter). Acta Agric Slov., 89 - 1, Auqust- str. 5 - 13

Trdan S, Žnidarčič D, Vidrih M (2007b) Control of Frankliniella occidentalis on glasshouse-grown cucumbers: an efficacy comparison of foliar application of Steinernema feltiae and spraying with abamectin. Russ I Nematol 15(1):25-34

Trdan S, Vidrih M, Andjus L, Laznik Ž (2009) Activity of four entomopathogenic nematode species against different developmental stages of Colorado potato beetle, Leptinotarsa decemlineata (Coleoptera, Chrysomelidae). Helminthologia 46(1):14-20

Wardlow LR, Piggott S, Goldsworthy R (2001) Foliar application of Steinernema feltiae for the control of flower thrips. Mededelingen Faculteit Landbouwkundige Toegepaste Biol Wetenschappen Univ Gent. Proceedings of 53rd International Symposium on Crop Protection, Gent, Belgium 66:285-291

Williams EC, Walters KFA (2000) Foliar application of the entomopathogenic nematode Steinernema feltiae against leafminers on vegetables. Biocontrol Sci Tech 10:61-70

Woodring, J. L., and Kaya, H. K. 1988. Steinernematid and heterorhabditid nematodes: a handbook of techniques. Southern cooperative series bulletin. 331. Fayetteville, AK: Arkansas Agricultural Experiment Station. pp. 30

\section{Submit your manuscript to a SpringerOpen ${ }^{\circ}$ journal and benefit from:}

- Convenient online submission

- Rigorous peer review

- Open access: articles freely available online

- High visibility within the field

- Retaining the copyright to your article 